\title{
Rapid nasopharyngeal brush-smear cytology with Epstein- Barr virus DNA load and viral marker analysis for detection of nasopharyngeal carcinoma
}

\author{
Ramayanti $\mathrm{O}^{1,4}$, Rachmadi L ${ }^{1}$, Kodariah R ${ }^{1}$, Handayani SI ${ }^{1}$, Budiningsih $\mathbf{I}^{1,3}$, Adham $\mathrm{M}^{2}$, Kurniawan AN ${ }^{1}$ and Middeldorp JM ${ }^{4 *}$ \\ ${ }^{1}$ Department of Anatomical Pathology, Dr. Cipto Mangunkusumo Hospital, University of Indonesia, Jakarta, Indonesia \\ ${ }^{2}$ Department of Ear, Nose and Throat-Head and Neck Surgery, Dr. Cipto Mangunkusumo Hospital, University of Indonesia, Jakarta, Indonesia \\ ${ }^{3}$ Department Immunology, Universitas Airlangga, Surabaya, Indonesia \\ ${ }^{4}$ Department of Pathology, VU University Medical Center, De Boelelaan 1117, 1081HV Amsterdam, The Netherlands
}

\begin{abstract}
Background: Nasopharyngeal carcinoma (NPC) is a prevalent cancer in Indonesia, usually identified at late stage. Epstein-Barr virus (EBV) gene products are present in all tumor cells. Early-stage NPC diagnosis is clinically important but difficult due to non- specific symptoms. In patients suspected of having NPC, nasopharyngeal (NP) brush-cytology may provide a simple non-invasive procedure for rapid on-site detection of NPC tumour cells that can be combined with EBV markers.

Methods: Patients (N=83) suspected of having NPC underwent nasoendoscopy-guided NP brushing before a biopsy from clinically suspicious areas. The loaded brush was first smeared onto glass slides that were directly immersed in ethanol, followed by Papanicolaou (PAP) staining and on-site interpretation of tumour cell presence. Thereafter, slides were used for EBER RNA in situ hybridization (EBER-ISH) and LMP-1 immunocytochemistry (ICC). The brush left-over was used for EBV-DNA load measurement using real-time PCR. Biopsy specimens were taken from the same NP site and processed for routine pathology and EBER-ISH on tissue sections.

Result: Morphological detection of NPC tumour cells on PAP-stained brush-smears gave a sensitivity and specificity of $87 \%$ and $100 \%$, respectively. EBER-RISH and LMP1 ICC combined showed 100\% positivity for NPC cases. Expression of LMP-1 was detected in 77.8\% of cases. Median EBV-DNA load in left-over brush material from NPC cases was $5.06 \times 10^{6}$ copies/brush (range 777 to $242,400,000$ copies/brush), whereas median value in non-NPC cases was $4.4 \times 10^{3}$ copies/brush (range $484-297,200 ; P<0.001$ ).

Conclusion: Minimal invasive NP-brush cytology with conventional PAP staining allows rapid, simple and cheap "on site" detection of NPC tumour cells in suspected NP lesions. The method can be modified for direct demonstration of EBV involvement using EBER-ISH and LMP1-ICC or EBV-DNA load measurement. This NP brush procedure may be useful for primary screening in patients considered at risk for NPC.
\end{abstract}

\section{Introduction}

Nasopharyngeal carcinoma (NPC) is a highly prevalent head and neck malignancy in most of south-east Asia, including Southern China, Taiwan, Hong-Kong, Vietnam, Thailand, Malaysia, Singapore and Indonesia. NPC is the fifth most frequent cancer in Indonesia, with a yearly incidence of 6.3 per 100.000 inhabitants, overall resulting in more than 12.000 new cases every year, being mainly of Javanese origin $[1,2]$.

Epstein-Barr Virus (EBV) is a double stranded DNA virus that infects human B-lymphocytes and epithelial cells [3]. Numerous investigations have demonstrated a strong correlation between EBV and NPC development [4]. This is supported by the clonal presence of EBV-DNA and distinct EBV gene expression in all tumor cells and by elevated levels and increased diversity of antibody reactivity to EBV antigens, in particular including IgA antibodies [4-7]. Moreover, NPC patients may have increased levels of circulating EBV DNA as measured in plasma or whole blood [8-10].

NPC is commonly diagnosed at advanced stage because of its hidden initiation site and non-specific symptoms at early stage [1]. Late diagnosis leads to poor survival [11-14]. Patients presenting with UICC-AJCC disease stage I or IIa may have 2-year survival of $90 \%$, whereas for stage IIb - IV the 2-year survival is less than 50\% despite aggressive concurrent chemoradiation therapy [12]. Recent clinical and population-based studies from Indonesia show an even worse outcome with most NPC patients in Indonesia having low socio-economic status, lack essential financial or insurance support and have difficulty to reach healthcare centers [13-16].

Since early-stage signs and symptoms of NPC are rather non-specific and not timely recognised, most patients already have enlarged upper cervical nodes, usually stage III or IV, at first presentation, resulting in poor prognosis and inferior treatment results [1,11-17]. Therefore, it is important to improve awareness on early-stage NPC among clinicians [18]. Foremost important is to combine increased awareness with

${ }^{\star}$ Correspondence to: Jaap M. Middeldorp, Department of Pathology, VU University Medical Center, De Boelelaan 1117, 1081HV Amsterdam, The Netherlands, Tel: +31-655750768, E-mail: j.middeldorp@amsterdamumc.nl

Key words: NPC, Brush-smear cytology, PAP-stain, EBV, LMP-1 IHC, EBER-ISH Received: January 18, 2021; Accepted: February 12, 2021; Published: February 18,2021 
locally accessible and affordable diagnostic and therapeutic options, by establishing a protocol for accurate NPC diagnosis and specific and effective treatment in the early stage of disease [19-21]. New treatment options aimed at targeting EBV inside the NPC tumor cells emphasize the need for EBV-related diagnostic procedures [19-21]. Prior studies reported EBV-specific IgA antibody testing or the combination of IgA antibody and EBV-DNA load measurement in blood or plasma to be useful for early detection of NPC, but the sensitivity and specificity of these methods are variable, although recent improvements show further promise $[6,9,10,22-26]$.

Endoscopic examination of the nasopharyngeal space, either transoral or trans nasal, may identify suspicious lesions, indicative of (early stage) NPC [5]. Current definitive diagnosis requires an invasive painful, sometimes repetitive, nasopharyngeal (NP) biopsy and pathological examination, preferably combined with in situ detection of EBV-specific nuclear EBER RNA [21,7]. More simple and preferably non-invasive methods are needed, especially for early NPC detection high-risk populations in developing countries and rural areas [13$15,28]$. Previous studies have shown the feasibility of using cell smears from NP swabs or brushings or fine-needle aspirates for detecting NPC tumor cells by standard cytology, providing a simple approach with a detection rate of approximately $80 \%$ [29-31]. A recent improvement is created by combining the non-invasive NP brush sampling with EBV-DNA load quantification and EBV-mRNA (BARF1 transcripts) detection, which provides a highly sensitive and specific method, which may replace the invasive biopsy [33-35]. The NP- brush/swab sample also allows for assessing the methylation status of characteristic tumorsuppressor genes or the EBV-specific C-promoter, which provide further confirmation of NPC tumor presence and activity [36-38]. Recently we provided further proof that cellular material collected by NP brushing truly represents NPC tumor tissue in situ [39]. Nowadays, NP-brush plus EBV-DNA quantification is being applied more widely [40-43]. Although the NP brush-PCR method proved very sensitive and specific, it requires expensive PCR technology and appropriate lab facilities that are not always available in regional or rural hospitals in high incidence (developing) countries. Therefore, a simple sampling procedure combined with on-site visual inspection for direct and accurate demonstration of NPC tumor cells may be desirable.

Here we describe a simple non-invasive NP brush procedure with standard Papanicolaou staining for direct in situ identification of abnormal cytology in the cell smear, which can subsequently be combined with detection of EBV small RNA (EBER) or antigen (LMP1) [44]. The method was validated against EBV-DNA load quantification in the 'left-over' material of the same brush. The pathological result from the NP biopsy, which was taken from the same site as the NP brushing, was considered as golden standard. This NP-brush PAP-stain procedure may be appropriate for use in regional public hospitals for primary NPC risk-assessment in populations considered at risk of (early stage) NPC because of persisting head and neck complaints. The procedure maybe combined with EBV-IgA serology in finger-tip blood and EBVDNA load measurement in left-over NP-brush material [33,34,45].

\section{Methods}

\section{Patient selection and specimen collection}

Eighty-three consecutive patients with ear, nose, throat (ENT) complaints suspected of having NPC underwent nasendoscopy and nasopharyngeal (NP) brushing before biopsy at Cipto Mangunkusumo Hospital, Jakarta, Indonesia. During nasoendoscopy, size and location of tumor was registered and classified as no visible tumor mass (normal), thickened nasopharynx (abnormal), protruding tumor mass (suspect tumor), and huge tumor mass (clear tumor). Examples of endoscopic NP abnormalities are shown in Figure 1 A-C. From 83 patients, $62(75 \%)$ proved to have NPC by biopsy with standard pathological criteria and EBER-RISH confirmation, leaving 21 cases as control having a variety of non-NPC diseases (Table 1). NP brushing was performed by experienced ENT-specialist and ENT-resident trainees as described before $[34,39,46]$. A detailed visualisation of the NP brush and biopsy procedure is shown in supplemental figure 1 and the supplemental video 1 . Briefly: The nasal cavity and nasopharynx were locally anesthetized with $4 \%$ lidocaine $\mathrm{HCl}$ spray (AstraZeneca, Södertälje, Sweden). For acquisition of nasopharyngeal cytology specimen, we used a gynecologic brush (Medscand Cytobrush, Trumbull, CT, USA), guided by rigid or flexible nasoendoscopy (Supplemental Figure 1). A protective plastic sheath covered the brush during nasal cavity passage to prevent the brush from collecting nasal cells or mucous as detailed before [34-36,39,46]. Once positioned at the site of suspected tumor mass in Fossa Rosenmuller area, the brush was pushed-out and rotated locally to obtain cell specimens (Supplementary video 1). The brush was then pulled into the sheath before removal from the nose to prevent contamination on the way out. The loaded brush was smeared on to $4-6$ glass slides which were immediately immmersed in $96 \%$ ethylalcohol to ensure good cell preservation. The remainder of the brush was placed in $4 \mathrm{ml}$ NucliSens Lysis buffer (BioMerieux, Marcy l'Etoile, France) for EBV-DNA load measurement using a Roche LightCycler-II PCR exactly as described before $[9,34,39]$. Biopsy specimens were taken immediately following brush sampling from the same site (Supplementary video 1).

\section{Cytological and histological examination}

For conventional cytology, slides were processed for Papanicolaou staining according to standard procedures. By blinded examination cases were divided into 2 groups, either suspected negative (no obvious tumor cells) or positive for NPC. The microscopic classification of the number of cells on the brush smear following standard Papanicolaou staining was, no tumor cell, few (1-5) tumor cells, moderate (5-25) tumor cells, and many $(>25)$ tumor cells. The positive group comprised cases with carcinoma-like tumour cells in clusters and/or individual epithelial tumor present on the slide, whereas the negative group comprised cases where only normal columnar epithelial cells and lymphocytes were found. Cytological diagnosis was later compared with the result of NP biopsy.

Monoclonal antibody-based latent membrane protein-1 (LMP1) immunocytochemistry (ICC) [44] and EBV encoded RNA (EBER) in-situ hybridization (ISH) were performed on ethanol-fixed smears of tumour cell positive cases and some of non-NPC cases as negative control as detailed below. All smear samples were examined by an experienced senior cytoscreener and a pathologist blinded to the
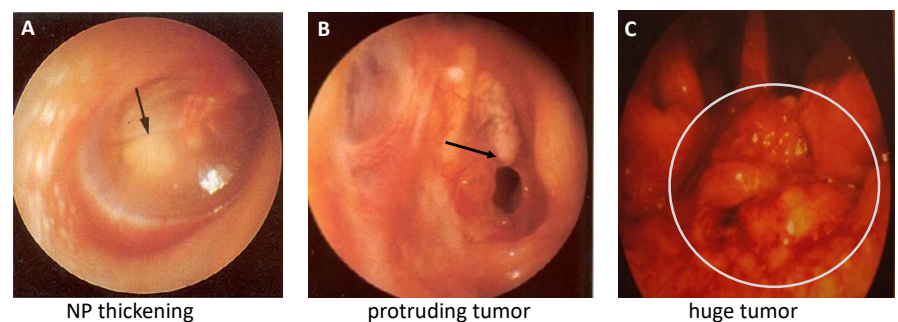

Figure 1. Endoscopic visualisation of nasopharyngeal (NP) abnormalities. Characteristic endoscopic images of A) NP wall thickening, B) protruding NP tumor mass and C) huge NP tumor mass. 
Table 1. The cytology result in cases with histology defined nasopharyngeal disease

\begin{tabular}{|l|c|c|c|}
\hline Histopathology result & $\begin{array}{c}\text { Positive } \\
\text { cytology }\end{array}$ & $\begin{array}{c}\text { Negative } \\
\text { cytology }\end{array}$ & $\begin{array}{c}\text { Total } \\
\text { cases }\end{array}$ \\
\hline NPC cases (n= 62) & \multicolumn{1}{|l|}{} \\
\hline Keratinizing Squamous cell carcinoma (WHO-1) & $1 / 1$ & $0 / 1$ & 1 \\
\hline Non-keratinizing Ca, differentiated (WHO-2) & $5 / 6$ & $1 / 6$ & 6 \\
\hline Non-keratinizing Ca, undifferentiated (WHO-3) & $48 / 55$ & $7 / 55$ & 55 \\
\hline Non-NPC cases (n= 21) & $4 / 8$ & $4 / 8$ & 8 \\
\hline Non-Hodgkin Lymphoma (NHL)* & $0 / 2$ & $2 / 2$ & 2 \\
\hline Nasal Polyp & $0 / 1$ & $1 / 1$ & 1 \\
\hline Adenocarcinoma & $0 / 10$ & $10 / 10$ & 10 \\
\hline Chronic Nasopharyngitis & & \\
\hline
\end{tabular}

* Cytomorphology of NHL cells on the PAP-smear was clearly different from NPC cells.

biopsy result. The parallel biopsy specimens (see supplementary video) were processed for standard formalin fixation, paraffin embedding and hematoxylin-eosin staining [30,31,34]. Biopsy EBER-ISH was performed using commercial reagents (DAKO, Glostrup, Denmark). The tissue sections were examined by two pathologists blinded to the cytology result.

\section{Epstein-Barr Encoded RNA In-situ hybridization (EBER-RISH)}

EBER-RISH was performed on the alcohol-fixed cytology slides and paraffin-embedded tissue sections using the EBER PNA probe RISH detection kit (DAKO) according to the manufacturer's instructions. For the cytosmears, briefly, after removal coverslide and mounting fluid by xylene immersion and marking the cell area, the slide was dried and pre-treated with proteinase $\mathrm{K}$ and hybridisation solution containing the FITC-conjugated peptide nucleic acid PNA probe was applied overnight at $+4 \mathrm{C}$. After intensive washing alkaline phosphatase-conjugated rabbit $\mathrm{F}(\mathrm{ab}$ ') anti-FITC was applied for 30 min and followed washing BCIP/NBT (bromochloro-indolyphosphate/ nitroblue tetrazolium chloride) was used as the chromogen. Slides were then lightly counterstained with haematoxylin Meyer's solution (Merck, Mannheim, Germany). Dark blue nuclear staining was identified as positive hybridisation signal. Each specimen was scored for EBER as negative or positive.

EBER-RISH were also performed on the biopsy specimens. Positive control slides were taken from confirmed EBV positive NPC cases. Negative control slide for each run were made by replacing the EBER probe with negative control probe (DAKO) or using an EBV negative breast or colon cancer tissue.

\section{Latent Membrane Protein- 1 (LMP-1) immunocytochemistry}

After diagnosis was performed on the conventional cytology slide, the location of cell smear was indicated underside each positive slide with a diamond pencil and then the slide was soaked in xylene to remove coverslip and mounting fluid. All positive cases were stained with anti-LMP-1 monoclonal antibody as described before [44]. Some of negative cases such as chronic nasopharyngitis, were also stained as negative controls. Slides were covered with $0.5 \%$ $\mathrm{H} 2 \mathrm{O} 2$ in methanol for blocking endogenous peroxidase, pre-treated subsequently with Tris-EDTA $\mathrm{pH} 9.0$ and heated in a microwave oven (Electrolux) for two consecutives 5 minute periods at high and low power setting, respectively. For blocking non-specific antibody binding sites, slides were then incubated with blocking buffer (1\% horse serum in PBS) and overnight with primary antibody (1:150 in blocking buffer) and antibody binding was visualized with biotinlabelled secondary antibodies and a streptavidin-peroxidase $A B C$ complex using di-aminobenzidine as a chromogenic subtrate (Dako,
Denmark). Immuno- staining interpretation was based on brown color in cytoplasm and/or membrane and reported as positive or negative for expression of LMP-1 [44].

\section{Epstein-Barr Virus DNA load examination}

The remainder of the brush specimen, following 4-6 times repeated cytosmearing, was immersed in $4 \mathrm{ml}$ of NucliSens lysis buffer (BioMerieux), mixed well and stored at $-80^{\circ} \mathrm{C}$ and shipped on dry ice to the Department of Pathology, VU University Medical Center, the Netherlands. The samples were processed for DNA isolation using a manual silica-based procedure and quantitative real time PCR targeting highly conserved DNA sequence in the EBNA-1 (BKRF1) gene exactly as previously described [34,39].

\section{Statistical analysis}

Statistical analysis was done by SPSS version 16.0 (SPSS Inc.) and GraphPad Prism 7.0 (GraphPad Software, Inc., La Jolla, California, USA). EBV DNA values between the patient and control groups were compared by using the Chi-Square test, unpaired t-test and KruskallWallis correlation test as detailed in the results section. A $P$-value below 0.05 was considered significant.

\section{Results}

Of the 83 consecutive patients suspected of having NPC, 61 (73.5\%) were male and $22(26.5 \%)$ were female, giving a male-female ratio of 2.7:1. The most common age was $41-50$ years in 24 cases (28.9\%), with the youngest patient being 17 years, the oldest 75 years, with a mean age of 45 years. Table 1 shows the results for 62 patients with histologically proven NPC and 21 cases diagnosed as non-NPC with the corresponding histopathological definition and cytological finding. Pathological examination of 62 NPC cases revealed 1 WHO type I, $6 \mathrm{WHO}$ type II and $55 \mathrm{WHO}$ type III cases, all being positive by EBER-ISH demonstrating 100\% EBV involvement (Figure 1A and 1B). Clinical staging combined with CT-scan revealed NPC stage III for $9 / 62(14.5 \%)$ cases, $39 / 62(62.9 \%)$ with stage IVa and 14/62 (22.5\%) with stage IVb.

On nasoendoscopic examination (Figure 2A-2C), 4/62 NPC cases (6.5\%) showed thickening of the nasopharynx, 48/62 cases (77.4\%) had a protruding tumor mass and $10 / 62$ cases $(16.1 \%)$ had a large tumor mass in the NP space. From 4 NPC cases with thickened NP appearance (Figure 2A) only one case lacked tumor cells on the cytology slide, whereas 7/48 (14.2\%) NPC cases with protruding tumor mass (Figure 2B) lacked tumor cells on cytology slide. All cases (100\%) with huge NP tumor mass (Figure 2C) revealed groups of tumor cells on the cytology slide (Figure 1C and 1D). NPC tumor cells generally arranged in clusters with round ovoid nuclei and prominent nucleoli, irregular nuclear membrane and scanty cytoplasm.

Occasionally NPC cells were present as single large cells or as small groups or sheets of large cells. Small and densely stained cells mainly consisted of lymphocytes, monocytes and granulocytes. In 4/8 nasal non-Hodgkin lymphoma (NHL) cases we observed distinct lymphoma tumor cells on the brush cytology slide and we did not find tumor cells in 1 case of adenocarcinoma. For the NHL cases the tumor cells were rounded and medium to large in size, arranged singly or in occasion scattered loose non-cohesive groups without moulding.

Most lymphoma cells had one or more moderate prominent nucleoli and mitotic figures could be found. No obvious tumor cells were found in the NP-brush smears of 10 cases of chronic nasopharyngitis and 2 cases of nasal polyp (Table 1). 

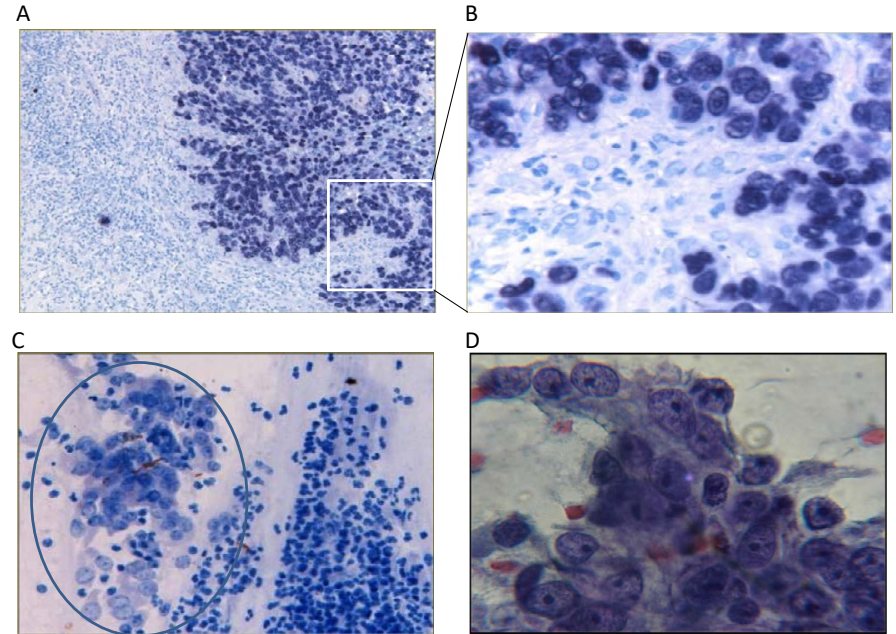

Figure 2. Identification of NPC tumor cells in tissue biopsy and PAP-stained NP brush cell smear. A) NPC tumor with EBV involvement as demonstrated by EBER-RISH in the routine formalin-fixed and paraffin-embedded (FFPE) histopathology biopsy specimen showing positive EBER RNA expression in nuclei of NPC tumor cells. B) (enlarged view) EBER- RISH in FFPE tissue specimen showing characteristic nuclear staining in the tumor cells only. C) Papanicolaou stained NP brush smear on glass slide visualizing enlarged NPC tumor cells (left side) presenting as single large cells or as groups/sheets of large cells. Small cells (right side) represent lymphocytes, monocytes and granulocytes. D) Conventional PAP- stained NP-brush smear cytology (enlarged view). Tumor cells arrange in clusters and have round /ovoid nuclei with prominent nucleoli, irregular nuclear membrane and scanty cytoplasm.

Overall, there was a significant association between endoscopic NP tumor appearance and number of tumor cells on the brush-smear slide (Figure 3; $\mathrm{p}<0.001$, Chi-square test) with $54 / 62$ pathologically confirmed NPC cases $(87.1 \%)$ showing clear endoscopic NP abnormality and carcinoma-type tumor cells by PAP-cytology (Figure 1C and 1D), 22 cases had abundant tumor cells, 15 cases had moderate amounts and 17 cases had only few tumor cells. Eight of 62 cases (12.9\%) had no clear endoscopic abnormality and lacked obvious tumor cells by PAP-cytology. These cases had only a small NPC lesion in the biopsy comprising 1/6 WHO type II and 7/55 WHO type III type tumors, all being EBER-RISH positive. Taking the biopsy result as gold standard, the diagnostic sensitivity of the brush cytology was $87 \%$, whereas the specificity was $100 \%$. We could not differentiate between WHO type of NPC. The single WHO type 1 case did not show keratin pearls or individual cell dyskeratosis on the glass slide even though there were some keratin pearls in the biopsy specimen.

From 54 of 62 NPC cases we obtained slide smears with sufficient cells that were suitable for EBER analysis. All 54 (100\%) were positive for EBER-ISH on the cytology slide and the parallel biopsy specimen (Figure 4A and 4B), including the one case of keratinizing squamous cell carcinoma (WHO-I). EBER staining clearly revealed the presence of sporadic NPC tumor cells within the NP brush smears, which might have escaped detection by PAP staining only (Figure 4B). Two cases of nasal NHL showed positivity for EBER-ISH in cytology slide which was confirmed by EBER-positivity in the paraffin-embedded biopsy specimen. None of 10 chronic nasopharyngitis cases were positive for EBER-ISH (Table 2). EBV encoded LMP1 is not equally expressed in all NPC tumors and its expression may affect tumor behaviour. In our cohort, $42 / 54(77.8 \%)$ of NPC patients with sufficient brush-smear slides were examined by monoclonal antibody-based ICC had LMP-1 detected in the nasopharyngeal brush cytology specimen, being 39/48 (81.3\%) WHO type III cases and 3/5 (60\%) for WHO type II (Figure 4C and $4 \mathrm{D}$ ). One case of WHO-I NPC was negative for LMP-1. All nonNPC and non-cancer cases, were negative for LMP-1 (Table 2).
EBV DNA viral load in NP brushing left-over specimens was analysed for 48 cases, consisting of 30 cases of NPC WHO type III, 3 cases of NPC WHO type II, 6 cases of chronic nasopharyngitis, 2 cases of nasal polyp, 6 cases of B-NHL and 1 case of adenocarcinoma (Figure 5). The level of EBV-DNA load in brush left-overs was variable for confirmed NPC cases and ranged from 777 to $242.4 \times 10^{6}$ copies/ brush (median $5.06 \times 10^{6}$ copies/brush), consistent with prior findings of extreme high viral DNA loads in NP-brushings from NPC cases (Figure 5A) [34,35,39,40-44]. Both lowest and highest viral load were observed NPC WHO type III cases. Non-NPC cancer and non-cancer cases had significantly lower EBV-DNA levels ranging from $484-29.7$ $\mathrm{x} 10^{4}$ copies/brush, with a median of $4.4 \times 10^{3}$ copies/brush $(\mathrm{p}<0.0001$, unpaired T-test). The highest and the lowest in this group were malignant B-NHL cases, but both cases did not have tumor cells on cytology slide. One NHL case was later classified as T-/NK-cell type granuloma and had $15.9 \times 10^{3} \mathrm{EBV}$-DNA copies in the brush and few lymphoid tumor cells on the cytology slide.

We evaluated the relation between EBV-DNA load in the left-over brush specimen and the visible tumor size in the nasopharynx (Figure 5B). Of the 48 cases that yielded viral load data, $3(6.3 \%)$ had no visible tumor mass, $11(22.9 \%)$ had a thickened nasopharynx, $29(60.4 \%)$ had a protruding tumor mass and $5(10.4 \%)$ showed a huge tumor mass. The

Table 2. Positivity of EBER-RISH and LMP-1 ICC in cytology smears

\begin{tabular}{|l|c|c|}
\hline Pathological status & EBER-RISH & LMP-1 \\
\hline Keratinizing squamous cell carcinoma (WHO-I) & $1 / 1$ & $0 / 1$ \\
\hline Non-keratinizing Ca, differentiated (WHO-II) & $5 / 5^{*}$ & $3 / 5^{*}$ \\
\hline Non-keratinizing Ca, undifferentiated (WHO-III) & $48 / 48^{*}$ & $39 / 48^{*}$ \\
\hline Chronic nasopharyngitis & $0 / 10$ & $0 / 10$ \\
\hline Nasal adenocarcinoma & $0 / 1$ & $0 / 1$ \\
\hline Nasal polyp & $0 / 2$ & $0 / 2$ \\
\hline $\begin{array}{l}\text { Non-Hodgkin Lymphoma (NHL)** } \\
\text { *: Not all brush smear slides could be re-analysed for EBER-ISH and LMP1-ICC; } \\
\text { **: For NHL only 4/8 cases had tumor cells on cytology slide. Two EBER positive cases } \\
\text { were later classified as NK/T-cell granuloma. }\end{array}$ \\
\hline
\end{tabular}

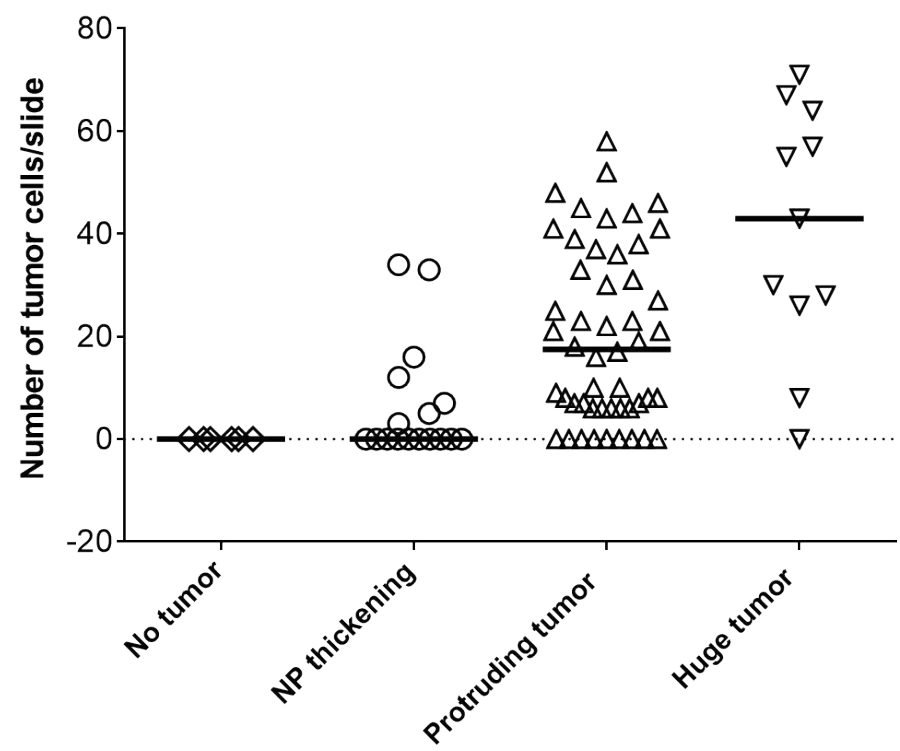

Figure 3. Numerical PAP-cytology result versus endoscopic appearance of the suspected NP-tumor lesion. The number of tumor cells on the PAP-smear slide was counted by two experienced cytologists unaware of the pathological status. The amount of tumor cells collected on the brush-slide increases with endoscopic size of the suspected tumor mass $(\mathrm{P}<0.001)$. 
A

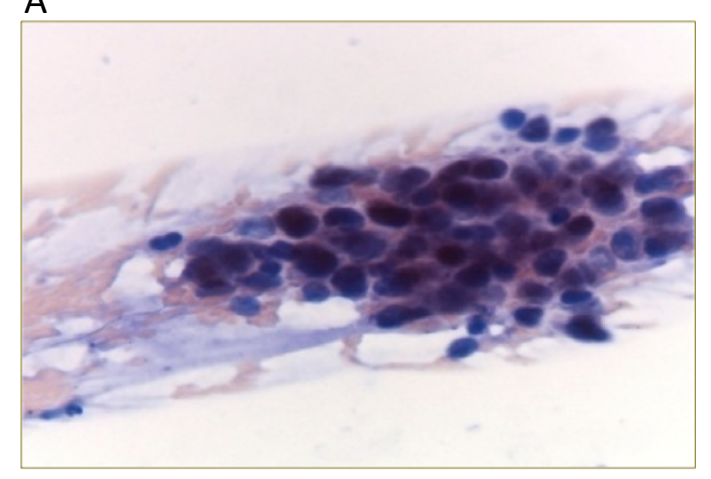

c

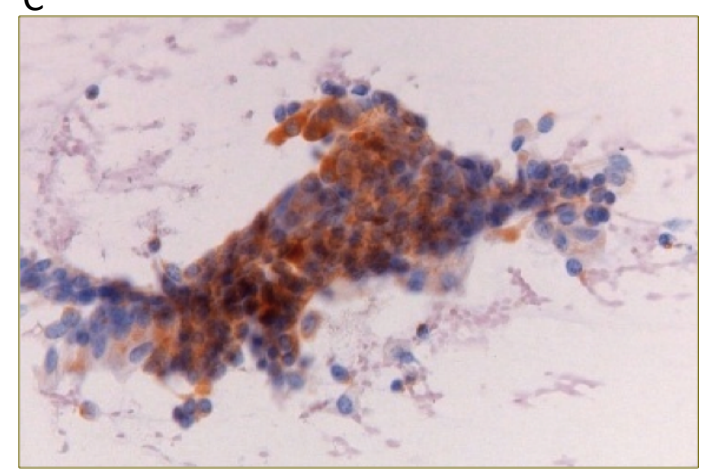

B

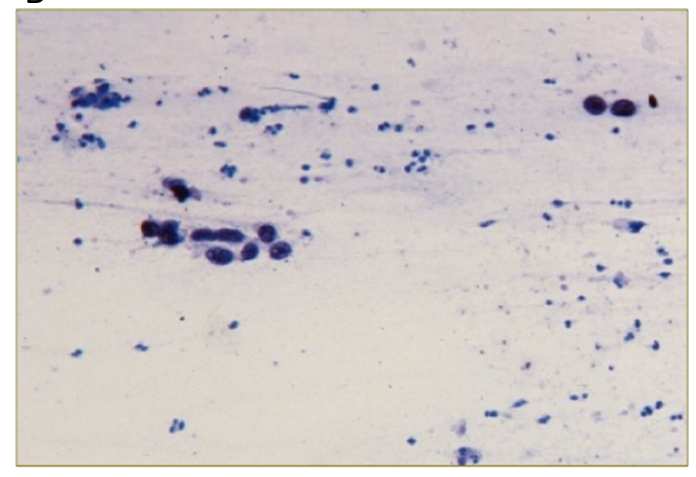

$\mathrm{D}$

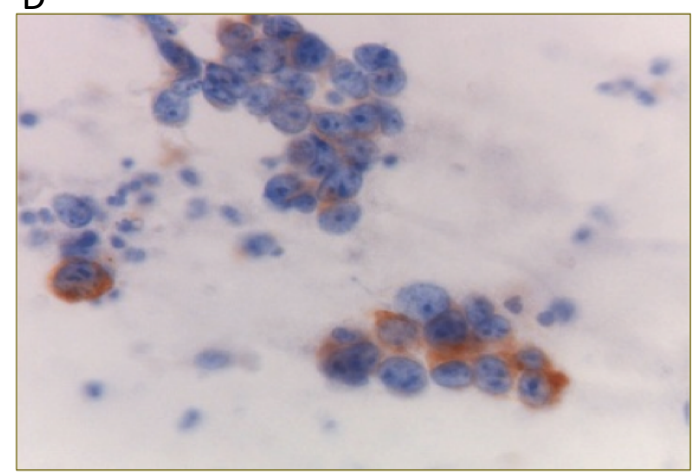

Figure 4. Detection of EBV-markers on NP-brush cytology slides. A) EBER-RISH directly on NP-brush smear cytology slide. A cluster of tumor cells show EBER expression in nuclei. B) EBER- RISH on NP-brush smear enhances the contrast for finding rare tumor cells. C) Expression of LMP-1 by monoclonal antibody-based immunocytochemistry (ICC) directly on the NP brush smear. LMP1 presence is revealed as brown staining in cytoplasm and membrane of tumor cells. D) (enlarged view) Expression ofLMP-1 by ICC in cytoplasm and membrane of NPC tumor cells.

A

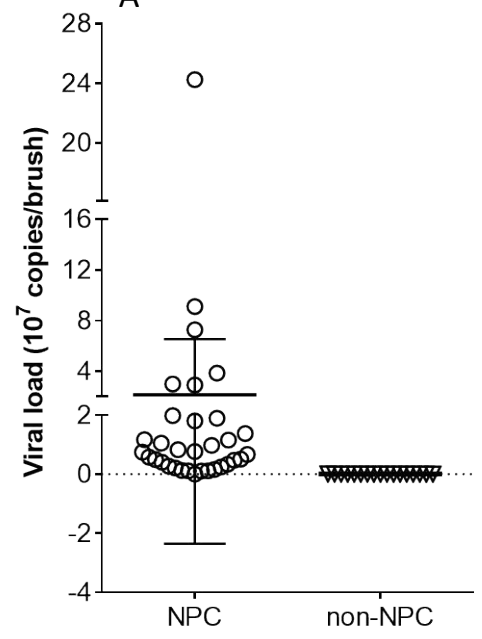

B

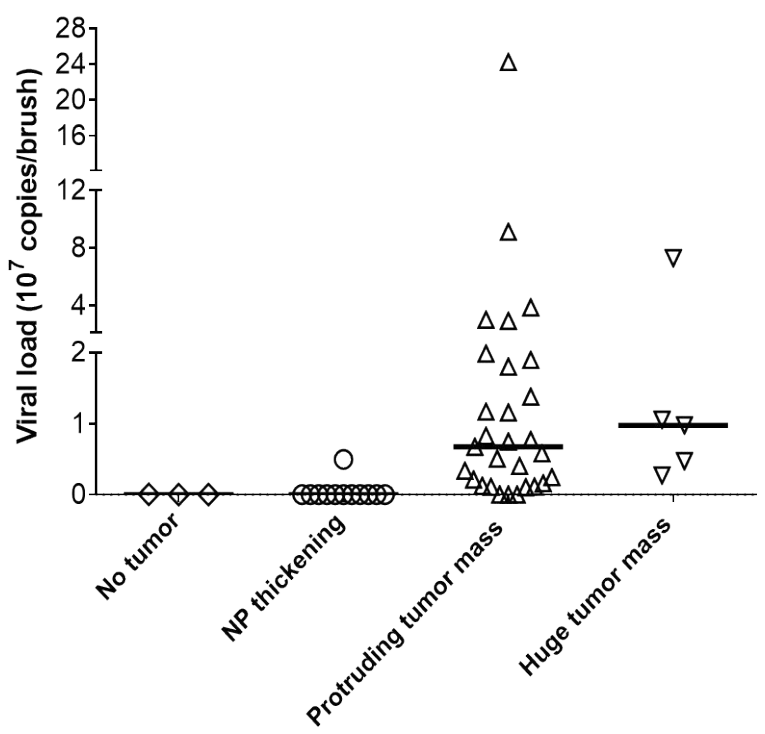

Figure 5. Epstein-Barr virus DNA load in the cytobrush of NPC and non-NPC cases. A) EBV DNA load was measured by realtime quantitative PCR in "left-over" samples after brush cytology smear preparation, still showing significantly elevated loads compared to controls. Statistical analysis comparing mean viral load in NPC and non-NPC case groups showed clear significant difference ( $<0.0001$; unpaired T-test). B) EBV DNA load measured in "left-over" brush samples versus tumor size by nasendoscopy. Statistical analysis showed significant relation between viral load and tumor size ( $\mathrm{p}<0.0001$; Kruskal- Wallis test). 
lowest of viral load was observed in a case with a thickened nasopharynx and the highest of viral load originated from a case with protruding tumor mass. Statistical analysis of the relation between viral load and tumor size using Kruskal-Wallis test showed a clear overall significance $(p<0.0001)$. Further analysis revealed significance for the difference in EBV - DNA load between no visible tumor mass versus moderate tumor mass ( $p=0.018)$, no tumor versus huge tumor mass $(p=0.025)$, thickened nasopharynx versus moderate tumor mass $(\mathrm{p}<0.002)$ and thickened nasopharynx versus huge tumor mass $(\mathrm{p}=0.004)$. There was no statistical difference in EBV DNA load between absence of visible tumor mass versus thickened nasopharynx $\mathrm{p}=0.697$ ) as well as for moderate versus huge tumor mass $(\mathrm{p}=0.319)$. The confirmed NPC cases without detectable tumor cells in the cytosmear, all contained EBV-DNA by PCR, ranging from $11.4 \times 10^{4}-24.2 \times 10^{6}$ copies/brush (median: $7.4 \times 10^{6}$ ).

Statistical analysis by Kruskal-Wallis test confirmed statistical significance between viral load level and total number of tumor cell on the slide $(\mathrm{p}=0.006)$.

\section{Discussion}

NPC patients, in particular in rural areas, usually come to the hospital at late stage with progressive disease because of having ignored non-specific clinical signs and symptoms at early stage [1,13-17]. In part, late-stage diagnosis is caused by the general difficulty in visualizing and recognizing abnormalities in the nasopharyngeal space at early stage of disease and by limited NPC awareness among hospital and health care workers [16-18]. Many tumors are detected late or remain undiagnosed until they present as lymphnode metastasis (lump) in the neck, sometimes without overt pathology at the primary site. ${ }^{21,27}$ Success of treatment in NPC patients is strongly related to the disease stage [14,15,19,21]. Earlystage NPC detection should significantly improve cure rate, reduce morbidity and incidence of metastasis $[21,46]$.

EBV-specific serology, -especially IgA-EBNA1 and IgA-VCA (EBV-IgA)-, is considered suitable for (early stage) NPC diagnosis and requires simple and generally available (commercial) immunoassay techniques [5-7,9,22,24,45,47]. Increased levels of EBV-IgA are frequently detectable before clinical onset of NPC which has resulted in population-wide screening and (early stage) NPC risk assessment studies in endemic areas, based on EBV-IgA testing $[46,48,49]$. Additionally, quantification of circulating EBV-DNA levels in whole blood, serum or plasma has been proposed for NPC diagnosis [8] but requires expensive equipment and currently lacks standardization and sensitivity for early-stage NPC detection [9,23-26,50,51].

A disadvantage of serological and molecular diagnostic methods is sample shipment and (distant) laboratory analysis. On site NPinspection and tumor visualisation with direct diagnosis of NPC in primary health care centers or regional hospitals would be a preferred option allowing direct referral or immediate intervention. Nasoendoscopy is a useful tool for direct examination of the nasopharyngeal cavity and is crucial in guiding a punch biopsy $[27,30]$. Nasopharyngoscopy alone has a high specificity (80-90\%) for the diagnosis of NPC, though its sensitivity (62\%) proved disappointing [30]. Ultrasound imaging may be used as alternative or complementary approach, but equally lacks the option of direct visualisation of tumor cells [52].

Confirmation of NPC tumor presence is achieved by taking a painful invasive biopsy from a suspected lesion in the NP-surface, followed by pathological examination, which is considered the standard procedure [27]. Minimal invasive NP brush/swab sampling and cytology has been described as a sensitive alternative diagnostic method for identification of NPC presence in the NP space [30-32]. Direct imprint cytology from the biopsy specimen gave a sensitivity of $87.2 \%$ [30,31]. Jan and colleagues introduced a preservation fluid for brush- cytology to improve the quality of cells on the glass smear, giving a sensitivity and specificity in diagnosing NPC of $84.2 \%$ and $96.6 \%$, respectively [32]. These studies show the feasibility of using simple NP brush/swab cytology for diagnosing NPC without need for expensive equipment. The NP-brushing/swab procedure is perceived by patients as much less painful compared to the biopsy and has reduced risk of inducing bleeding in the NP-space (see comparison of NP brushing and biopsy in the supplementary video 1) [47]. Our recent molecular studies have confirmed that NP-brush/swab sampling provides direct evidence for local NPC tumor presence [39]. This is reflected by extremely elevated levels of tumor-derived (Cp- methylated) EBV-DNA, which are not observed in healthy EBV carriers or patients with chronic nasopharyngitis nasal polyps or non-NPC malignancies [33-35,40-43]. The NP-brush/swab material allows EBV latent and lytic RNA profiling [34,39], host and viral DNA methylation analysis [36-39] and direct tumor-associated viral DNA sequencing [53,54]. Unfortunately, these molecular methods are not widely available (yet) in regional hospitals where NPC patients first present.

In this study we evaluated the non-invasive cytobrush procedure with direct on-site PAP-staining of cell smears and microscopy to detect NPC tumor cells following nasendoscopy (Figure 2). A biopsy was taken in parallel from the same site (Supplementary video 1) and processed for routine pathology. The remainder of the NP-brush sample was processed for EBV-DNA load by quantitative PCR. Of 83 consecutive suspect cases considered at risk of having NPC, 62 cases proved to be true NPC cases as defined by pathological examination of the biopsy and 21 proved to be non-NPC (Table 1). Direct cytological examination identified 54/62 NPC cases by simple PAP-staining and microscopy at the site of sample collection, resulting in a sensitivity and specificity of $87 \%$ and $100 \%$, respectively. Cytomorphology of the brush-sampled cells was similar to imprint cytology from the primary NP-biopsy or fine needle aspiration cytology from cervical lymph node or another metastatic site [30-32]. The tumor cells appear in clusters and/or as individual epithelial cells and are easily identified by morphology only. The clusters of tumor cells are formed by overlapping nuclei in a syncytial pattern with pale cytoplasms and indistinct cell border (Figure 1C-1D). Our study is first in parallel analysing EBV markers on the brush cell-smear and EBV-load measurement in leftover brush material as confirmation of EBV involvement in the tumor specimen. All NPC cases (100\%) showed positive EBER-ISH result, and LMP-1 ICC was positive in $67.7 \%$ cases (42/62). This is in accordance with other studies, showing $60-80 \%$ LMP-1 positivity in 87 NPC cases [44]. Additionally, in the brush left-over samples of NPC cases the mean EBV viral load was $19.7 \times 10^{6} \mathrm{copies} / \mathrm{brush}$, whereas in non-NPC cases the mean value was $29 \times 10^{3}$ copies/brush, a highly significant ( $>600$ fold) difference $(\mathrm{p}<0.0001)$. This result confirms that the non-invasive NP brush technique with quantitative EBV-DNA load measurement is useful to differentiate NPC from non-NPC cases with high sensitivity and specificity and may replace the biopsy [34,37-43]. Unfortunately, this added methodology requires further laboratory facilities for sample processing (DNA extraction), delicate reagent handling and expensive PCR technology, which is not always available in regional hospital settings.

The NP-brush PAP-smear method described here may be wellsuited for use in developing countries such as Indonesia, where specialized academic centers and regional hospitals are limited, but where a good line of local health care facilities is available [11-16]. 

carcinoma

The proposed procedure is simple and rapid, producing a cytology smear with $96 \%$ alcohol fixation and PAP staining for direct diagnostic analysis under the microscope. The cytology results closely correlated with subsequent molecular analysis of EBV-DNA load $(\mathrm{p}=0.006)$. Further improvement of awareness about signs and symptoms of NPC in rural communities and local health care workers and improving readily available diagnostic options will improve recognition of NPC at earlier stages, ensuring proper referral and timely treatment initiation [11-16,19]. NP endoscopic examination and on-site NP-brush PAP-cytology is proposed as first-line diagnostic procedure for "at-risk" cases defined in population screening studies and for patients with undefined head and neck complaints suspected as having NPC, as was demonstrated in this study $[1,17,55]$. Further improvement in cyto-preservation technology may make NP brush cytology equally effective for NPC screening as classic PAP-smear cytology for the detection of cervical cancer $[32,56]$.

\section{Conclusion}

Non-invasive NP-brush cytology with conventional Papanicolaou staining allows rapid, simple and cheap detection of putative NPC tumour cells in suspected NP lesions, observed by nasoendoscopy. The method can be modified for direct visualisation of EBV involvement using EBER-RISH and LMP1-ICC and extended by EBV-DNA load quantification in the remaining left-over NP-brush specimen. This may improve early-stage NPC detection rate, timely referral and yield better treatment results of this aggressive tumor, in particular in regional hospitals in developing countries, where access to molecular diagnostic technology is still limited.

\section{Supplemental Information}

\section{Supplemental Video}

\section{Acknowledgements}

This study was supported by the Netherlands Cancer Society grants KWF-VU2006-21 and KWF-VU2010-4809 awarded to JMM. We thank patients and residents at Dr. Cipto Mangunkusumo Academic Hospital, Jakarta, Indonesia for their collaboration.

\section{References}

1. Adham M, Kurniawan AN, Muhtadi AI, Roezin A, Hermani B, et al. (2012) Nasopharyngeal carcinoma in Indonesia: epidemiology, incidence, signs, and symptoms at presentation. Chin J Cancer 31: 185-196. [Crossref]

2. Sun X, Tong LP, Wang YT, Wu YX, Sheng HS, et al. (2011) Can global variation of nasopharynx cancer be retrieved from the combined analyses of IARC Cancer Information (CIN) databases? PLoS One. 6: e22039. [Crossref]

3. Cohen JI (2000) Epstein-Barr virus infection. New Engl J Med 343: 481-492.

4. Tao Q, Chan AT (2007) Nasopharyngeal carcinoma: molecular pathogenesis and therapeutic developments. Expert Rev Mol Med 9: 1-24. [Crossref]

5. Zong YS, Sham JS, Ng MH, Ou XT, Guo YQ, et al. (1992) Immunoglobulin A against viral capsid antigen of Epstein-Barr virus and indirect mirror examination of the nasopharynx in the detection of asymptomatic nasopharyngeal carcinoma. Cancer 69: 3-7. [Crossref]

6. Chang C, Middeldorp J, Yu KJ, Juwana H, Hsu WL, et al. (2013) Characterization of ELISA detection of broad-spectrum anti-Epstein-Barr virus antibodies associated with nasopharyngeal carcinoma. J Med Virol 85: 524-529. [Crossref]

7. Fachiroh J, Schouten T, Hariwiyanto B, Paramita DK, Harijadi A, et al. (2004) Molecular diversity of Epstein-Barr virus IgG and IgA antibody respons in nasopharyngeal carcinoma: a comparison of Chinese, Indonesian and European cases. J Infect Dis 190: 53-63. [Crossref]

8. Chan KC, Lo YM (2002) Circulating EBV DNA as tumor marker for nasopharyngeal carcinoma. Semin Cancer Biol 12: 489-496. [Crossref]
9. Stevens SJC, Verkuijlen SAWM, Hariwiyanto B, Harijadi, Fachiroh J, et al. (2005) Diagnostic value of measuring Epstein-Barr virus (EBV) DNA load and carcinomaspecific viral mRNA in relation to anti-EBV immunoglobulin A (IgA) and IgG antibody levels in blood of nasopharyngeal carcinoma patients from Indonesia. J Clin Microbiol 43: 3066-3073. [Crossref]

10. Gulley ML, Tang W (2008) Laboratory assays for Epstein-Barr virus related disease. $J$ Mol Diagn 10: 279-292. [Crossref]

11. Du Y, Zhang W, Lei F, Yu X, Li Z, et al. (2020) Long-Term Survival After Nasopharyngeal Carcinoma Treatment in a Local Prefecture-Level Hospital in Southern China. Cancer Manag Res 12: 1329-1338. [Crossref]

12. Abdullah MM, Foo YC, Yap BK, Lee CML, et al. (2019) Retrospective Analysis of Cancer Care Performance and Survival Outcome for Nasopharyngeal Carcinoma at a leading Cancer Treatment Centre in Malaysia 2008-2012. Asian Pac J Cancer Prev 20: 1701-1708. [Crossref]

13. Adham M, Stoker SD, Wildeman MA, Rachmadi L, Gondhowiardjo S, et al. (2014) Current status of cancer care for young patients with nasopharyngeal carcinoma in Jakarta, Indonesia. PLoS One 9: e102353. [Crossref]

14. Hutajulu SH, Howdon D, Taroeno-Hariadi KW, Hardianti MS, Purwanto I, et al. (2021) Survival outcome and prognostic factors of patients with nasopharyngeal cancer in Yogyakarta, Indonesia: A hospital-based retrospective study. PLoS One 16: e0246638. [Crossref]

15. Dwijayanti F, Prabawa A, Besral, Herawati C (2020) The Five-Year Surviva Rate of Patients with Nasopharyngeal Carcinoma Based on Tumor Response after Receiving Neoadjuvant Chemotherapy, Followed by Chemoradiation, in Indonesia: A Retrospective Study. Oncology 98: 154-160. [Crossref]

16. Fles R, Bos ACRK, Supriyati, Rachmawati D, Waliyanti E, et al. (2017) The role of Indonesian patients' health behaviors in delaying the diagnosis of nasopharyngeal carcinoma. BMC Public Health 17: 510. [Crossref]

17. Lee AW, Foo W, Law SC, Poon YF, Sze WM, et al. (1997) Nasopharyngeal carcinoma: presenting symptoms and duration before diagnosis. Hong Kong Med $J$ 3: 355-361. [Crossref]

18. Wildeman MA, Fles R, Adham M, Mayangsari ID, Luirink I, et al. (2012) Shortterm effect of different teaching methods on nasopharyngeal carcinoma for general practitioners in Jakarta, Indonesia. PlosOne 7: e32756. [Crossref]

19. Hutajulu SH, Kurnianda J, Tan IB, Middeldorp JM (2014) Therapeutic implications of Epstein- Barr virus infection for the treatment of nasopharyngeal carcinoma. Ther Clin Risk Manag 10: 721-736. [Crossref]

20. Tsang J, Lee VH, Kwong DL (2014) Novel therapy for nasopharyngeal carcinoma-where are we? Oral Oncol 50:798-801. [Crossref]

21. Chen YP, Chan ATC, Le QT, Blanchard P, Sun Y, Ma J (2019) Nasopharyngeal carcinoma. Lancet 394: 64-8022. [Crossref]

22. Fachiroh J, Paramita DK, Hariwiyanto B, Harijadi A, Dahlia HL, et al. (2006) Single assay combination of Epstein-Barr virus (EBV) EBNA-1 and viral capsid antigen p18 derived synthetic peptides for measuring anti-EBV immunoglobulin $\mathrm{G}$ (IgG) and IgA antibody levels in sera from nasopharyngeal carcinoma patients: options for field screening. J Clin Microbiol 44: 1459-1467. [Crossref]

23. Ji MF, Huang QH, Yu X, Liu Z, Li X, et al. (2014) Evaluation of plasma Epstein-Barr virus DNA load to distinguish nasopharyngeal carcinoma patients from healthy highrisk populations in Southern China. Cancer 120: 1353-1360. [Crossref]

24. Tan LP, Tan GW, Sivanesan VM, Goh SL, Ng XJ, et al. (2020) Malaysian Nasopharyngeal Carcinoma Study Group. Systematic comparison of plasma EBV DNA, anti-EBV antibodies and miRNA levels for early detection and prognosis of nasopharyngeal carcinoma. Int J Cancer 146: 2336-2347. [Crossref]

25. Chan KCA, Woo JKS, King A, Zee BCY, Lam WKJ, et al. (2017) Analysis of plasma Epstein-Barr Virus DNA to screen for nasopharyngeal cancer. $N$ Engl J Med 377: 513 522. [Crossref]

26. Lam WKJ, Jiang P, Chan KCA, Cheng SH, Zhang H, et al. (2018) Sequencing-based counting and size profiling of plasma Epstein-Barr virus DNA enhance population screening of nasopharyngeal carcinoma. Proc Natl Acad Sci U S A 115: E5115-E5124. [Crossref]

27. Sham JS, Wei WI, Zong YS, Choy D, Guo YQ, et al. (1990) Detection of subclinical nasopharyngeal carcinoma by fibreoptic endoscopy and multiple biopsy. Lancet 335 : 371-374. [Crossref]

28. Devi BC, Pisani P, Tang TS, Parkin DM (2004) High incidence of nasopharyngeal carcinoma in native people of Sarawak, Borneo Island. Cancer Epidemiol Biomarkers Prev 13: 482-486. [Crossref] 
29. Feinmesser R, Miyazaki I, Cheung R, Freeman JL, Noyek AM, et al. (1992) Diagnosis of nasopharyngeal carcinoma by DNA amplification of tissue obtained by fine needle aspiration. N Engl J Med 326: 17-21. [Crossref]

30. Chang AR, Liang XM, Chan AT, Chan MK, Teo PM, et al. (2001) The use of brush cytology and directed biopsies for the detection of nasopharyngeal carcinoma and precursor lesions. Head Neck 23: 637-645. [Crossref]

31. Tsou MH, Wu ML, Chuang AY, Lin CY, Terng SD (2006) Nasopharyngeal biopsy imprint Cytology: A retrospective analysis of 191 cases. Diagn Cytol 34: 204-207. [Crossref]

32. Jan YJ, Chen SJ, Wang J, Jiang RS (2009) Liquid-based cytology in diagnosing nasopharyngeal carcinoma. Am J Rhinol Allergy 23: 422-425. [Crossref]

33. Sheen TS, Ko JY, Chang YL, Chang YS, Huang YT, et al. (1998) Nasopharyngeal swab and PCR for the screening of nasopharyngeal carcinoma in the endemic area: a good supplement to the serologic screening. Head Neck 20: 732-728. [Crossref]

34. Stevens SJC, Verkuijlen SAWM, Hariwiyanto B, Harijadi, Paramita DK, et al. (2006) Non-invasive diagnosis of nasopharyngeal carcinoma: nasopharyngeal brushing reveal high Epstein-Barr virus DNA load and carcinoma specific viral BARF1 mRNA. Int $J$ Cancer 119: 608-614. [Crossref]

35. Coghill AE, Wang CP, Verkuijlen SAWM, Yu KJ, Hsu WL, et al. (2018) Hildesheim Evaluation of nasal and nasopharyngeal swab collection for the detection of EpsteinBarr virus in nasopharyngeal carcinoma. J Med Virol 90: 191-195. [Crossref]

36. Hutajulu SH, Indrasari SR, Indrawati LP, Harijadi A, Duin S, et al. (2011) Epigenetic markers for early detection of nasopharyngeal carcinoma in a high risk population. $\mathrm{Mol}$ Cancer 10: 48. [Crossref]

37. Zhang Z, Sun D, Hutajulu SH, Nawaz I, Nguyen Van D, Huang G, et al. (2012) Development of a non-invasive method, multiplex methylation specific PCR (MMSP), for early diagnosis of nasopharyngeal carcinoma. PLoS One 7: e45908. [Crossref]

38. Zheng XH, Wang RZ, Li XZ, Zhou T, Zhang JB, et al. (2020) Detection of methylation status of Epstein-Barr virus DNA C promoter in the diagnosis of nasopharyngeal carcinoma. Cancer Sci 111: 592-600. [Crossref]

39. Ramayanti O, Juwana H, Verkuijlen SA, Adham M, Pegtel MD, et al. (2017) EpsteinBarr virus mRNA profiles and viral DNA methylation status in nasopharyngeal brushings from nasopharyngeal carcinoma patients reflect tumor origin. Int $J$ Cancer 140: 149-162. [Crossref]

40. Zheng XH, Lu LX, Li XZ, Jia WH (2015) Quantification of Epstein-Barr virus DNA load in nasopharyngeal brushing samples in the diagnosis of nasopharyngeal carcinoma in southern China. Cancer Sci 106: 1196-1201. [Crossref]

41. Ng RH, Ngan R, Wei WI, Gullane PJ, Phillips J (2014) Trans-oral brush biopsies and quantitative PCR for EBV DNA detection and screening of nasopharyngeal carcinoma. Otolaryngol Head Neck Surg 150: 602-629. [Crossref]

42. Chen Y, Zhao W, Lin L, Xiao X, Zhou X, et al. (2015) Nasopharyngeal Epstein-Bar Virus Load: An Efficient Supplementary Method for Population-Based Nasopharyngeal Carcinoma Screening. PLoS One 10: e0132669. [Crossref]
43. Zhang PF, Zheng XH, Li XZ, Tian T, Zhang SD, et al. (2018) Nasopharyngeal brushing: a convenient and feasible sampling method for nucleic acid-based nasopharyngeal carcinoma research. Cancer Commun (Lond) 38: 8. [Crossref]

44. Khabir A, Karray H, Rodriguez S, Rosé M, Daoud J, et al. (2005) EBV latent membrane protein 1 abundance correlates with patient age but not with metastatic behaviour in north African nasopharyngeal carcinomas. Virol J 2: 39. [Crossref]

45. Fachiroh J, Prasetyanti PR, Paramita DK, Prasetyawati AT, Anggrahini DW, et al. (2008) Dried-blood sampling for Epstein-Barr virus immunoglobulin G (IgG) and IgA serology in nasopharyngeal carcinoma screening. J Clin Microbiol 46: 1374-1380. [Crossref]

46. Ji MF, Sheng W, Cheng WM, Ng MH, Wu BH, et al. (2019) Incidence and mortality of nasopharyngeal carcinoma: interim analysis of a cluster randomized controlled screening trial (PRO-NPC-001) in southern China. Ann Oncol 30: 1630-1637. [Crossef]

47. Adham M, Greijer AE, Verkuijlen SA, Juwana H, Fleig S, et al. (2013) Epstein-Barr virus DNA load in nasopharyngeal brushings and whole blood in nasopharyngeal carcinoma patients before and after treatment. Clin Cancer Res 19: 2175-2186. [Crossref]

48. Ji MF, Wang DK, Yu YL, Guo YQ, Liang JS, et al. (2007) Sustained elevation of Epstein-Barr virus antibody levels preceding clinical onset of nasopharyngeal carcinoma. Br J Cancer 96: 623-630. [Crossref]

49. Liu Z, Ji MF, Huang QH, Fang F, Liu Q, et al. (2013) Two Epstein-Barr virus-related serologic antibody tests in nasopharyngeal carcinoma screening: results from the initial phase of a cluster randomized controlled trial in Southern China. Am J Epidemiol 177: 242-250. [Crossref]

50. Nicholls JM, Lee VH, Chan SK, Tsang KC, Choi CW, et al. (2019) Negative plasma Epstein-Barr virus DNA nasopharyngeal carcinoma in an endemic region and its influence on liquid biopsy screening programmes. Br J Cancer 121: 690-698. [Crossref]

51. Kim KY, Le QT, Yom SS, Pinsky BA, Bratman SV, et al. (2017) Current State of PCRBased Epstein-Barr Virus DNA Testing for Nasopharyngeal Cancer. J Natl Cancer Inst 109: djx007. [Crossref]

52. Gao Y, Liu JJ, Zhu SY, Yi X (2014) The diagnostic accuracy of ultrasonography versus endoscopy for primary nasopharyngeal carcinoma. PLoS One 9: e9041. [Crossref]

53. Correia S, Palser A, Elgueta Karstegl C, Middeldorp JM, Ramayanti O, et al. (2017) Natural Variation of Epstein-Barr Virus Genes, Proteins, and Primary MicroRNA. $J$ Virol 91: e00375-17. [Crossref]

54. Correia S, Bridges R, Wegner F, Venturini C, Palser A, et al. (2018) Sequence Variation of Epstein-Barr Virus: Viral Types, Geography, Codon Usage, and Diseases. J Virol 92 e01132-e1138. [Crossref]

55. Hutajulu SH, Fachiroh J, Argy G, Indrasari SR, Indrawati LPL, et al. (2017) Seroprevalence of $\operatorname{IgA}$ anti Epstein-Barr virus is high among family members of nasopharyngeal cancer patients and individuals presenting with chronic complaints in head and neck area. PLoS One 12: e0180683. [Crossref]

56. Pankaj S, Nazneen S, Kumari S, Kumari A, Choudhary V, et al (2018) Comparison of conventional Pap smear and liquid-based cytology: A study of cervical cancer screening at a tertiary care center in Bihar. Indian J Cancer 55: 80-83. [Crossref]

Copyright: (C2021 Ramayanti O. This is an open-access article distributed under the terms of the Creative Commons Attribution License, which permits unrestricted use, distribution, and reproduction in any medium, provided the original author and source are credited. 